\title{
The Guarani Aquifer Agreement and Transboundary Aquifer Law in the SADC: Comparing Apples and Oranges?
}

\author{
Francesco Sindico* and Stephanie Hawkins
}

International law governing transboundary aquifers is considerably underdeveloped, with only a handful of bilateral and multilateral agreements governing specific aquifer systems to date. However, the significance of transboundary aquifers in addressing water security concerns is gaining recognition, and dialogue discussing the future of the international legal framework is growing in importance. Contributing to this dialogue, we seek to compare different legal instruments applicable to the management of transboundary aquifers in different regions. We draw from the experience of the processes that led to an established transboundary agreement in one region, and compare it to another region that is yet to establish a formal legal instrument. Specifically, we compare the Guarani Aquifer System in Latin America with international legal instruments applicable to the management of transboundary aquifers in the Southern African Development Community (SADC). We identify several trends arising from the management of the Guarani Aquifer System that could have potentially valuable input for SADC countries currently embarking upon the initial stages of the management of a transboundary aquifer. Central to this article is the underlying question of whether these international legal instruments, which are placed in dramatically different contexts, can be compared in the first place. We conclude that such a comparison is useful only if undertaken as a process of knowledge acquisition, as such a broad comparative exercise is limited in its ability to produce direct policy recommendations. Gaining knowledge of regional governance practices in relation to differing aquifer characteristics is particularly important in this underdeveloped area, especially as discussions regarding the future for transboundary aquifer law are gaining momentum at the international level.

\section{INTRODUCTION}

Can you compare international legal arrangements for transboundary aquifers that are so radically different that it could be considered comparing apples to oranges? This article addresses this question by focusing on the legal instruments applicable to the management of transboundary aquifers in two different regions. The article thus moves away from a more traditional comparative law approach in which the laws and policies from different countries are compared. Instead, it considers international law instruments applicable to the Guarani Aquifer System in Latin America and international legal instruments applicable to the management of transboundary aquifers in the Southern African Development Community (SADC).

Such a comparison is challenging, as it involves comparing something that already exists (the international legal instrument regarding the management of the Guarani Aquifer System, the Guarani Aquifer Agreement) with something that has yet to emerge (there are no international legal instruments devoted specifically to the management of a transboundary aquifer system in the SADC region). To enable the comparison, the article will look closely at the Guarani Aquifer Agreement ${ }^{1}$ as the ad hoc international legal instrument applicable to the Guarani Aquifer System, and a panoply of different regional SADC-related international legal

\footnotetext{
* Corresponding author.

Email: francesco.sindico@strath.ac.uk

${ }^{1}$ Acuerdo Sobre el Acuífero Guarani (San Juan, 2 August 2010; not yet in force), ('Guarani Aquifer Agreement').
} 
instruments, which are mainly geared to transboundary surface water bodies. These include the SADC Revised Protocol, ${ }^{2}$ the Orange Senque River Commission (ORASECOM) treaty ${ }^{3}$ and the Limpopo Water Course Commission Agreement (LIMCOM). ${ }^{4}$ Notwithstanding the difficulty of comparing something that already exists to something that is not yet present, we hold that a comparison of these regional approaches is valuable for the underdeveloped area of transboundary aquifer law, as lessons for the future governance of aquifers in the SADC can be drawn from established legal instruments and their surrounding context. The Guarani Aquifer Agreement is an ideal point of comparison due, in part, to the presence of donor interventions, which are now also becoming prominent in the SADC region in relation to transboundary aquifers. ${ }^{5}$

This comparative exercise will involve the following steps. First, we set the scene by providing some contextual information about groundwater and transboundary aquifers. We move on to highlight the emerging international law of transboundary aquifers (TBAs) and provide details about the Guarani Aquifer System and TBAs in the SADC region. The following sections seek to shed some light on emerging practices arising from the management of the Guarani Aquifer System with a view to assessing what implications, if any, these practices may have on the management of TBAs in the SADC region. Next, we inquire whether a comparative assessment of this nature is even possible in the first place, whether it can lead to any policy-relevant outcomes and, if so, under what circumstances such a comparative exercise can be replicated for other TBA systems. We then draw some more general conclusions.

\section{TRANSBOUNDARY AQUIFERS}

Groundwater is of crucial importance for global water security. An estimated 96 percent of available freshwater resources (excluding water in glaciers and icecaps) are stored underground. ${ }^{6}$ Furthermore, in many parts of the world groundwater is already the main water source, ${ }^{7}$ and in some cases the only source for domestic and other needs. ${ }^{8}$ Reliance on groundwater is set to increase due to further stresses on surface freshwater linked to current

\footnotetext{
${ }^{2}$ Revised Protocol on Shared Watercourses in the Southern African Development Community (Windhoek, 7 August 2000; in force 22 September 2003) ('SADC Revised Protocol').

${ }^{3}$ Agreement between the governments of the Republic of Botswana, the Kingdom of Lesotho, the Republic of Namibia, and the Republic of South Africa on the Establishment of the Orange-Senqu River Commission (Windhoek, 3 November 2000) ('ORASECOM treaty').

${ }^{4}$ Agreement between the Republic of Botswana, the Republic of Mozambique, the Republic of South Africa and the Republic of Zimbabwe on the Establishment of the Limpopo Watercourse Commission (Maputo, 27 November 2003; in force 24 June 2005) ('LIMCOM treaty').

${ }^{5}$ Despite the differences, the two cases seem to follow a similar path towards more formal management of the TBAs. In the Guarani Aquifer System, it started with increasing knowledge about a little-understood TBA system, brokered partly through international donor projects, and followed by intergovernmental negotiations, ultimately leading to an agreement. A similar pattern is emerging in the SADC, with States showing increased interest in discussions over their transboundary aquifers as a result of increased knowledge through donor interventions.

${ }^{6}$ I. Shiklomanov, 'World Fresh Water Resources', in: P. Gleick (ed.), Water in Crisis: A Guide to the World's Fresh Water Resources (Oxford University Press, 1993), 13, at 13.

${ }^{7}$ I.S. Zekster and L.G. Everett, Groundwater Resources of the World and their Use (UNESCO-IHP-VI, 2004).

${ }^{8}$ M. Alker, The Stampriet Artesian Aquifer Basin: A Case Study for the Research Project 'Transboundary Ggroundwater Management in Africa (German Development Institute, 2008); California Water Boards, Communities that Rely on a Contaiminated Groundwater Source for Drinking Water: Report to the Legislature (State Water Resources Control Board, 2013).
} 
climate change trends, ${ }^{9}$ increased global population ${ }^{10}$ and unsustainable socio-economic patterns. $^{11}$

When groundwater is stored in an underground geological formation, it is found in an aquifer. ${ }^{12}$ When an aquifer is found under the territory of two or more States it is a transboundary aquifer. Over the last fifteen years, there has been a huge development in information collected about the world's TBAs, with current estimates putting the number of TBAs (and groundwater basins) at around six hundred. ${ }^{13}$ This is a large number, especially considering that only a handful have some sort of legal and institutional setting to regulate how they should be managed. ${ }^{14}$ In some cases these are non-binding soft legal instruments that focus mainly on promoting exchange of information, ${ }^{15}$ and do not enter into any detail about the substantial or institutional arrangements for the management of the TBA. In other cases, the TBA is governed by a legally binding instrument that provides a very detailed management framework. ${ }^{16}$ At the general international level it has been, again, only in the last decade or so that the international community has started to pay attention to the law governing TBAs. This has led the United Nations International Law Commission (UN ILC) to adopt Draft Articles on the Law of Transboundary Aquifers in 2008. ${ }^{17}$ Seven years later, the future legal form of these Draft

\footnotetext{
${ }^{9}$ Intergovernmental Panel on Climate Change (IPCC), Climate Change 2014: Synthesis Report. Contribution of Working Groups I, II and III to the Fifth Assessment Report of the Intergovernmental Panel on Climate Change (IPCC, 2014).

${ }^{10}$ The planet's biosphere and natural resources cannot sustain the current rate of population growth. See United Nations Department of Economic and Social Affairs et al., Population Dynamics in the Post-2015 Development Agenda (Report of the Global Thematic Consultation on Population Dynamics, 2013). For impacts of population growth on water resources see: M.T. Griffin, B.E. Montz and J.S. Arrigo, 'Evaluating Climate Change Induced Water Stress: A Case Study of the Lower Cape Fear Basin, NC' 40 Applied Geography (2013), 115; S. Pfister et al., 'Projected Water Consumption in Future Global Agriculture: Scenarios and Related Impacts' 409:20 Science of the Total Environment (2011), 4206.

${ }^{11}$ See IPCC, n. 9 above, at 54.

12 J. Margat and J. van der Gun, Groundwater around the World: A Geographic Synopsis (CRC Press, 2013).

${ }^{13}$ International Groundwater Resources Assessment Centre (IGRAC), Transboundary Aquifers of the World-the Special Edition for the 7 World Water Forum 2015 (IGRAC, 2015).

${ }^{14}$ Convention Relative a la Protection, a l'Utilisation, a la Realimentation et au Suivi de la Nappe Souterraine Franco-Suisse du Genevois (Geneva, 18 December 2007; in force 1 January 2008), ('Genevese Agreement'); Guarani Aquifer Agreement, n. 1 above; Agreement between the Government of the Hashemite Kingdom of Jordan and the Government of the Kingdom of Saudi Arabia for the Management and Utilization of the Ground Waters in the Al-Sag/Al-Disi Layer (signed 30 April 2015), unofficial English translation by Dr Sami Shubber, found at: <http://www.internationalwaterlaw.org/documents/regionaldocs/Disi_Aquifer_AgreementEnglish2015.pdf $>$ ('Disi Aquifer Agreement'); Establishment of a Consultation Mechanism for the Northwestern Sahara Aquifer System (SASS) (Rome, 19-20 December; endorsed 6 January 2003 (Algeria), 15 February 2003 (Tunisia), 23 February 2003 (Libya), $<$ http://www.fao.org/docrep/008/y5739e/y5739e05.htm\#bm05.2.1> ('NWSAS Agreement'); Programme for the Development of a Regional Strategy for the Utilisation of the Nubian Sandstone Aquifer System (NSAS) - Terms of Reference for the Monitoring and Exchange of Groundwater Information of the Nubian Sandstone Aquifer System (Tripoli, 5 October 2000), found at: <http://www.fao.org/docrep/008/y5739e/y5739e05.htm> ('NSAS Agreement'); Memorandum of Understanding for the Establishment of a Consultation Mechanism for the Integrated Management of the Water Resources of the Iullemeden, Taoudeni/Tanezrouft Aquifer Systems (ITAS) (Algeria, Benin, Burkina Faso, Mali, Mauritania, Niger, Nigeria), ( $2^{\text {nd }}$ Council of Ministers of Gicresait Project, Abuja, Nigeria, 28 March, found 2014), at: $<$ http://www.internationalwaterlaw.org/documents/regionaldocs/Iullemeden_MOU-2014.pdf> ('Iullemeden Agreement').

${ }^{15}$ This is the case, for example, for the NSAS Agreement, n. 14 above, and the NWSAS Agreement, n. 14 above.

${ }^{16}$ This is the case for the Genevese Agreement, n. 14 above.

17 International Law Commission Draft Articles on the Law of Transboundary Aquifers (UNGA Resolution A/RES/63/124, 11 December 2008) ('Draft Articles').
} 
Articles is still uncertain, ${ }^{18}$ but they have arguably had some effects, starting with the Guarani Aquifer Agreement, ${ }^{19}$ which was signed by Argentina, Brazil, Uruguay and Paraguay in $2010 .^{20}$

The Guarani Aquifer System is a TBA system located in Latin America. Despite the recent droughts suffered by the state of São Paulo, ${ }^{21}$ and the increasing pressure on the Guarani Aquifer System as a result, this TBA has not suffered great challenges in terms of water quantity and water quality. ${ }^{22}$ However, as the droughts show very clearly, climate change will soon put more pressure on the Guarani Aquifer System, creating unprecedented challenges for its management. Furthermore, the territory in which the TBA is located is home to more than 80 million people, ${ }^{23}$ most of which are based in Brazil. A wide range of socio-economic activities, from agro-industry to thermal tourism, is emblematic of the wide use of groundwater in the region. ${ }^{24}$ The aquifer system is one of the largest in the world and estimates suggest the amount of freshwater is sufficient to quench the thirst of the global population for the next 2,000 years at the current levels of consumption. ${ }^{25}$ Still, some areas of the aquifer are relatively unknown, ${ }^{26}$ with uncertainty as to the exact amount of water contained therein.

Almost twenty TBAs have been mapped in the SADC region. ${ }^{27}$ However, in contrast to the Latin American context, most of the TBAs in the SADC are rather small, and some are extremely localized. ${ }^{28}$ While most of the regions in which the Guarani Aquifer System is present are rich in surface water and have decent amounts of rainfall, most regions within the SADC are semi-arid with very dry conditions. ${ }^{29}$ In some cases TBAs underlie deserts, and groundwater present in the aquifers is the only freshwater available. ${ }^{30}$ Moreover, while the Guarani Aquifer System is situated in one of the most highly populated areas of Latin America, with sprawling cities like São Paulo, the same cannot be said for some TBAs in the SADC. In

${ }^{18}$ G.E. Eckstein and F. Sindico, 'The Law of Transboundary Aquifers: Many Ways of Going Forward by Only One Way of Standing Still', 23:1 Review of European, Comparative and International Environmental Law (2014), 32. The Draft Articles may lead to an international treaty, a UN General Assembly declaration of principles or remain as they are: draft articles annexed to a UN General Assembly Resolution.

19 D. McRae, 'The Work of the International Law Commission, 2007-2011: Progress and Prospects', 106:2 American Journal of International Law (2012), 322, at 325.

${ }^{20}$ Guarani Aquifer Agreement, n. 1 above. The preamble of the Guarani Aquifer Agreement refers specifically to the ILC's Draft Articles. This is relevant, since the Guarani Aquifer Agreement is only the second international legally binding instrument (treaty) adopted on the management of a TBA, the first one being the Genevese Agreement, n. 14 above.

${ }^{21}$ J. Watts, 'Brazil's Worst Drought in History Prompts Protests and Blackouts', The Guardian (23 January 2015 ).

${ }^{22}$ See Project for Environmental Protection and Sustainable Development of the Guarani Aquifer System, 'Guarani Aquifer Strategic Action Programme' (2009) ('SAP'), found at: < http://iwlearn.net/iwprojects/974/reports/strategic-action-program/view>, at 68-75.

23 S. Foster et al., The Guarani Aquifer Initiative - Towards Realistic Groundwater Management in a Transboundary Context (World Bank, 2009).

${ }^{24}$ L. Amore and U. Tröger, 'Transboundary Guarani Aquifer System and groundwater management mechanisms', in: Proceedings of the ISARM 2010 International Conference 6-8 December 2010 'Transboundary Aquifers: challenges and new directions' (UNESCO-IAH-UNEP, 2010).

${ }^{25}$ Ibid., at 2.

${ }^{26}$ See S. Foster et al., n. 23 above, at 27.

${ }^{27}$ K. Villholth and Y. Altchenko, Transboundary Aquifer Mapping and Management in Africa (International Water Management Institute and Consultative Group for International Agriculture Research, 2014).

28 SWECO International et al., 'Explanatory Brochure for the Southern African Development Community (SADC) Hydrogeological Map and Atlas' (Deutsche Gesellschaft für Technische Zusammenarbeit (GTZ), 2009).

${ }^{29}$ Climate change is exacerbating these conditions with downward trends in rainfall and temperature rises. See SADC, Climate Change Adaptation in SADC: A Strategy for the Water Sector (SADC, 2011).

${ }^{30}$ See M. Alker, n. 8 above, at 185. 
some cases the population 'served' by the TBAs in the SADC is almost negligible. ${ }^{31}$ Whether the groundwater contained in the aquifer reaches more or less people, one characteristic of TBAs in the SADC is their fragility in the face of increasing climatic changes as well as aggressive socio-economic patterns. Climate change is a key challenge for the SADC region and groundwater can play an important role in adapting to climate impacts. ${ }^{32}$ Furthermore, several governments in the region have authorized unconventional oil and gas exploration ${ }^{33}$ and mining has been a key historical economic activity ${ }^{34}$ together with (large- and small-scale) farming. ${ }^{35}$ Farming and the extractive industry can be very water-intensive and can also have a significant (negative) impact on the quality of the groundwater stored in a TBA. This is particularly concerning when ecosystems rely on groundwater to function properly.

The Guarani Aquifer System and TBAs in the SADC thus display different hydrogeological and socio-economic characteristics. Acknowledging these differences, the following sections of this article will focus on whether any patterns have emerged in the journey leading to the adoption of the Guarani Aquifer Agreement, which could be of interest for the management of TBAs in the SADC region.

\section{THE ELEMENTS TRIGGERING THE GUARANI AQUIFER AGREEMENT: IMPLICATIONS FOR THE SADC REGION}

While the Guarani Aquifer Agreement is one of the few TBA related international treaties, no TBA in the SADC is subject to an ad hoc international agreement. This section highlights the role of science in the process leading up to the Guarani Aquifer Agreement, together with other possible elements that could have triggered the agreement itself.

\section{THE ROLE OF SCIENCE IN THE RUN-UP TO THE GUARANI AQUIFER AGREEMENT}

In discussing the role of science in the run-up to the Guarani Aquifer Agreement, two considerations can be made: (i) science as such can sketch a clearer picture of what needs to be managed; and (ii) collaborative projects can boost the understanding of a TBA and help build political agreement.

First, a better understanding of the science surrounding the Guarani Aquifer System has helped dispel several 'hydromyths' that were poisoning debates about transboundary water management in the Guarani region before hydrogeologists from the four Guarani Aquifer System countries had the chance to clarify the true nature of how aquifers operated. Some

${ }^{31}$ W. Scheumann and M. Alker, 'Cooperation on Africa's Transboundary Aquifers - Conceptual Ideas', 54:4 Hydrological Sciences Journal (2009), 793, at 795.

${ }^{32} \mathrm{~K}$. Villholth, 'The Neglected Role of Groundwater in Climate Change Adaptation and Disaster Risk Reduction', 6 IOP Conference Series: Earth and Environmental Science (2009), 292062. See also SADC, n. 29 above.

${ }^{33}$ S. Esterhuyse, M. Kemp and N. Redelinghuys, 'Assessing the Existing Knowledge Base and Opinions of Decision Makers on the Regulation and Monitoring of Unconventional Gas Mining in South Africa', 38:6 Water International (2013), 687; D. Brown, Africa's Booming Oil and Natural Gas Exploration and Production: National Security Implications for the United States and China (Strategic Studies Institute and US Army War College Press, 2013); M. Stark et al., International Development of Unconventional Resources: If, Where and How Fast? (Accenture, 2014).

${ }^{34}$ B.H. Usher and P.D. Vermeulen, 'The Impacts of Coal and Gold Mining on the Associated Water Resources in South Africa', in: Y. Xu and B.H. Usher (eds.), Groundwater Pollution in Africa (Taylor \& Francis, 2006 ), 301.

${ }^{35}$ E. Braune and Y. Xu, 'Groundwater Management Issues in Southern Africa - An IWRM perspective', 34:6 Water SA (2008), 699; K.G. Villholth, 'Groundwater Irrigation for Smallholders in Sub-Saharan Africa - A Synthesis of Current Knowledge to Guide Sustainable Outcomes’, 38:4 Water International (2013), 369. 
stakeholders, for example, believed that all the water could be drawn from a single well, ${ }^{36}$ while there was also a widespread belief that the aquifer functioned very much like a large underground river. ${ }^{37}$ Not only were these beliefs refuted (except partly in the case of karstic aquifers), ${ }^{38}$ they were also unhelpful in bringing policy makers together.

It is possible that similar hydromyths exist that need to be washed away in the SADC region regarding groundwater and TBAs. For instance, more and better informed scientific research could help determine whether countries should proceed to authorize unconventional oil and gas exploitation, and what risks such activities pose to groundwater quality and quantity. In contrast to what happened in the Guarani Aquifer System, such research may well confirm the hydromyth that shale gas exploration and exploitation poses risks to aquifers. ${ }^{39}$

Second, and very much linked to the first point, the history leading to the Guarani Aquifer Agreement highlights that international projects can build and strengthen political trust. While hydrogeologists from the four Guarani Aquifer countries had exchanged studies and information already in the late $1990 \mathrm{~s},{ }^{40}$ it was mainly thanks to the Guarani Project that this exchange of information became institutionalized. ${ }^{41}$ The Guarani Project started in 2003 and was completed in 2009 when a Strategic Action Programme was published, capturing the key hydrogeological, environmental, socio-economic and legal institutional elements of the TBA. ${ }^{42}$ It also provided a series of clear institutional follow ups to sustainably manage the Guarani Aquifer System. ${ }^{43}$ The Guarani Project, which ran from 2003 to 2009, was funded by the Global Environment Facility (GEF) and the four countries (Argentina, Brazil, Paraguay and Uruguay), and implemented by the Organization of American States. Although it was met with scepticism from civil society in its early days due to the presence of foreign consultancies and the GEF, ${ }^{44}$ the Guarani Project has been hailed by many as the turning point in the management of the Guarani Aquifer System. ${ }^{45}$ It was this project that helped build the body of scientific knowledge needed to build solid foundations for a possible political agreement between the four countries.

Can a similar pattern be observed in the context of the TBAs in the SADC region, with international projects bringing together different disciplines and at the same time contributing to building the necessary trust between different national decision makers? Slowly, but steadily, there seems to be some progress, and international projects are starting to focus not only on transboundary surface water, as was once the case, ${ }^{46}$ but also on transboundary

\footnotetext{
${ }^{36}$ United Nations Environment Programme (UNEP), Freshwater Law and Governance: Global and Regional Perspectives for Sustainability (UNEP, 2015), at 95.

${ }^{37}$ Misunderstandings and hydromyths in relation to the Guarani Aquifer mainly existed because of a lack of available knowledge. See L. Amore, 'The Guarani Aquifer: From Knowledge to Water Management', 27:3 International Journal of Water Resources Development (2012), 463.

${ }^{38}$ See J. Margat and J. van der Gun, n. 12 above.

${ }^{39}$ B. Peek, M. Lewis and I. Teuling, 'Shell: Don't Frack the Karoo' (GroundWork, 2014).

40 J. Taks, El Acuifero Guaraní en Debate (Editorial Cotidiano Mujer, 2009).

${ }^{41} \mathrm{See}<$ http://www.oas.org/en/sedi/dsd/IWRM/Past_Projects/Guarani/project default.asp $>$.

${ }^{42}$ See SAP, n. 22 above. The Guarani Aquifer Strategic Action Programme was one of the last outcomes of the project, and summarizes the main results and key recommendations.

${ }^{43}$ Ibid.

${ }^{44}$ See J. Taks, n. 40 above.

45 See F. Sindico, 'The Guarani Aquifer System and the International Law of Transboundary Aquifers', 13:3 International Community Law Review (2011), 255, at 258 ('the increase in scientific knowledge of the Guarani Aquifer System is due especially to the Guarani Project').

${ }^{46}$ I. Baum and M. Nierenköther (eds.), Donor Activity in Transboundary Water Cooperation in Africa: Results of a G8-initiated Survey 2004-2007 (GTZ, 2007), found at: <http://www2.gtz.de/dokumente/bib/07-0778.pdf>.
} 
aquifers. UNESCO is leading a multidisciplinary project funded by the Swiss Agency for Development and Cooperation, aimed at increasing the understanding of the Stampriet Aquifer, shared by Botswana, Namibia and South Africa ${ }^{47}$ The aim of this project is for the countries to develop an institutional arrangement that will facilitate a coordinated exchange of information. The Stampriet project is part of a bigger project that also looks at TBAs in Eurasia and in Central America. A second TBA that is currently being studied is the Ramotswa Aquifer, shared by Botswana and South Africa. In this case the donor is USAID and the goal is to develop a better scientific understanding of the aquifer, but also to promote cooperation amongst the two aquifer States. ${ }^{48}$ In addition, the Ramotswa Aquifer is now one of several TBAs that will be studied by a large GEF project in which TBA law and policy constitutes one of the work packages. This project will establish a SADC Groundwater Management Institute at the University of the Free State in South Africa. ${ }^{49}$ This institute could play a pivotal role in the years to come by boosting awareness of transboundary aquifer management in the region. This project follows a completed SADC project that started putting groundwater and TBA management more firmly on the map in the context of providing policy responses to droughts and climate change. ${ }^{50}$

The emergence of these international projects is welcome. However, the current approach to identifying and developing projects on TBA management is still fragmented. Better coordination between implementing agencies and donors could be beneficial for the long-term management of TBAs in the SADC, as well as building synergies between already existing projects and new developments, such as the establishment of the SADC Groundwater Management Institute. The collaboration between actors and stakeholders involved in the ongoing Stampriet and Ramotswa projects is promising in this sense.

At the same time, the history of the Guarani Aquifer System shows that civil society and local authorities can receive international projects with scepticism. ${ }^{51}$ In the case of the Guarani Aquifer, it was in some cases seen as an intrusion on their national sovereignty, which, at least in part, could help explain the strong reference to sovereignty in the Guarani Aquifer Agreement. ${ }^{52}$ This reluctance to accept the involvement international donors seems to be less of a problem in the SADC region. However, projects need to engage constructively with local and regional stakeholders and decision makers in order for countries and users to feel not only represented, but also to consider it worthwhile to follow up and take ownership of these projects once they are completed.

In conclusion, science played a key role in furthering international cooperation on TBA management in the case of the Guarani Aquifer System. On the one hand, it could be argued

\footnotetext{
47 The Groundwater Resources Governance in Transboundary Aquifers Project (GGRETA), found at: $<$ http://www.groundwatercop.iwlearn.net/ggreta> ('GGRETA Project').

${ }^{48}$ This project is mentioned in a GGRETA Project meeting report: GGRETA Project, 'Groundwater Resources Governance in Transboundary Aquifers, Kalahari-Karoo/ Stampriet Aquifer: Report, First Regional Meeting' (UN House, Windhoek, Namibia 22-24 October 2013), found at: $<$ http://groundwatercop.iwlearn.net/ggreta/2_StamprietFirstMeetingReport.pdf $>$, at 10.

${ }^{49}$ P. Ramoeli and L. Croneborg, 'Sustainable Groundwater Management in SADC Member States: Project Brief' (SADC et al., 2013).

${ }^{50}$ SADC, 'Groundwater and Drought Management Project', found at: <http://iwlearn.net/iw-projects/970>.

${ }^{51}$ See J. Taks, n. 40 above.

${ }^{52}$ See F. Sindico, n. 45 above, at 260-262; L. Del Castillo Laborde, 'The Law of Transboundary Aquifers and the Berlin Rules on Water Resources (ILA): Interpretive Complementarity', in: Proceedings of the ISARM 2010 International Conference 6-8 December 2010 'Transboundary Aquifers: challenges and new directions' (UNESCO-IAH-UNEP, 2010).
} 
that until the countries know what they are regulating they should not move forward with transboundary cooperation. On the other hand, the opposite could be also true, and possibly more convincing. Precisely because of the scientific uncertainty about the nature of an aquifer, countries should be encouraged to leave aside their differences and consider joint management practices aimed at increasing their level of understanding of the aquifer through joint studies and exchanges of information. ${ }^{53}$ The example of the Guarani Aquifer System may fall within the first category (transboundary cooperation following an increased scientific understanding of the aquifer), ${ }^{54}$ while TBA management in the SADC fits more comfortably in the latter (transboundary cooperation despite a lack of thorough scientific understanding).

\section{INTERNATIONAL LAW GUIDELINES, WATER CONFLICTS AND NATIONAL WATER LAW IN THE RUN-UP TO THE GUARANI AQUIFER AGREEMENT}

We now turn to the other elements that can be said to have triggered the 2010 Guarani Aquifer Agreement. These elements include an adequate scientific understanding of the aquifer, the availability of general guidelines in international law, and an end to a long-lasting political tension in the region over transboundary water resources. ${ }^{55}$ To these we can add a fourth element: the existence of mature domestic legal and regulatory systems for groundwater management.

Let us consider each one of these factors more closely to see whether there are any similarities for the case of the SADC region. We have already mentioned how the work of researchers in the Guarani region, together with the outcomes of the Guarani Project, had enhanced the level of scientific understanding of the aquifer. We have also shown that a network of projects is emerging in the SADC region.

Moving on to considerations of the presence of general international law guidelines, it can be noted that in the case of the Guarani Aquifer System, countries attempted to negotiate a treaty to put forward the main rules and institutions for the management of the TBA in 2005, but failed. Two elements that had changed when the agreement was signed in 2010 were the new ILC's Draft Articles and the end of the Pulp Mills dispute. ${ }^{56}$ In the SADC region, one can see in the TBA-related project documents and in some SADC water policy documents references to the ILC's Draft Articles. ${ }^{57}$ The latter are now acknowledged as a possible 'guidance' for the future management of transboundary aquifers. ${ }^{58}$ This is important, because it means that once regional stakeholders and decision makers start to consider the regulation and management of transboundary aquifers, they can avail of UN-endorsed guidelines. Whether the end of the Pulp

\footnotetext{
53 The Draft Articles on the Law of Transboundary Aquifers recognize this in Article 8; see Draft Articles, n. 17 above. The Guarani Aquifer Agreement, n. 1 above, refers to this in Article 12.

${ }^{54}$ With the caveat that even for the Guarani Aquifer System there are still plenty of areas (especially in Argentina where the aquifer is deeper) where knowledge of the aquifer is still very limited. See S. Foster et al. n. 23 above, at 27; Z.P. Sugg et al., 'Transboundary Groundwater Governance in the Guarani Aquifer System: Reflections from a Survey of Global and Regional Experts', 40:3 Water International (2015), 377.

55 See F. Sindico, n. 45 above.

${ }^{56}$ ICJ 20 April 2010, Pulp Mills on the River Uruguay (Argentina v. Uruguay), [2010] ICJ Rep. 14 ('Pulp Mills'). The Pulp Mills Dispute was an environmental dispute between Argentina and Uruguay (two countries also sharing the Guarani Aquifer system) over the construction of pulp plant mills on the Uruguayan side of the River Uruguay that flows between the two countries.

${ }^{57}$ See GGRETA Project, n. 47 above, at 10; G. Christelis et al., 'Towards Transboundary Aquifer management in Southern Africa', in: Proceedings of the ISARM 2010 International Conference 6-8 December 2010 'Transboundary Aquifers: Challenges and New Directions (UNESCO-IAH-UNEP, 2010).

${ }^{58}$ Report of the Sixth Committee, The Law of Transboundary Aquifers (UN Doc. A/68/470, 19 November 2013), at paragraph 1; see G.E. Eckstein and F. Sindico, n. 18 above, at 34-35.
} 
Mills dispute between Uruguay and Argentina really played a role in adopting the Guarani Aquifer Agreement is a matter of speculation. ${ }^{59}$

Finally, one of the conclusions of the Guarani Project was that, although not perfect, the domestic legal systems of the four countries sharing the Guarani Aquifer System was mature and well-positioned to deal with groundwater challenges. ${ }^{60}$ If and when the Guarani Aquifer Agreement enters into force, ${ }^{61}$ the alleged maturity of the domestic legal systems will play an important role in the implementation of the agreement. ${ }^{62}$ The SADC shows an interesting picture in this respect, with some countries possessing laws that are not just mature, but quite progressive in terms of water resources management, with the laws hailed as models for other countries. Namibia, for example, possesses specific sections on groundwater management in its Water Act, and at an institutional level it provides the possibility of creating basin authorities focusing on specific hydrology and hydrogeological features of its water resources, including aquifers. ${ }^{63}$ The SADC region also includes countries (e.g. Zambia), whose water laws refer directly to international water law principles. ${ }^{64}$ Consequently, if there is to be an agreement between countries within the SADC region on the management of a transboundary aquifer, such an agreement would be embedded in existing national legal, regulatory and institutional frameworks. As in the Guarani Aquifer System, most countries have a mature domestic legal system that would be capable of providing (at least in writing) the necessary legal and regulatory tools for the implementation of the transboundary agreement.

Furthermore, the SADC region already has put in place a large number of transboundary surface water agreements and institutions that could prove useful when considering the management of TBAs in the region. We will address this point in the next section.

\section{A DOCTRINAL ANALYSIS OF THE GUARANI AGREEMENT: IMPLICATIONS FOR THE SADC REGION}

This section will highlight a few key characteristics emerging from a doctrinal analysis ${ }^{65}$ of the Guarani Aquifer Agreement. As we will explain further below, we do not suggest that other regions, including the SADC, should look to the Guarani experience as a model. There is, however, merit in sharing practices and experiences.

\section{THE GUARANI AQUIFER AGREEMENT EXPERIENCE}

\footnotetext{
${ }^{59}$ Pulp Mills, n. 56 above; see F. Sindico, n. 45 above, at 260. It has also been speculated that the agreement was the result of concern by stakeholders on the local level that future conflicts may arise between the countries; see Z.P. Sugg et al., n. 54 above, at 391.

${ }^{60}$ See SAP, n. 22 above, at 105-106. See the national water legislation in the Guarani Aquifer System region: Argentina General Environmental Law 25.675; Argentina Environmental management of Water Law 25.688; Paraguay Law on Water Resources, Law 3239 of 10 July 2000; Brazil National Water Resources Policy, Law no. 9.433 of 1997; Uruguay Water Code 1978 (as amended in 1987 and 1991).

${ }^{61}$ The Guarani Aquifer Agreement, n. 1 above, still needs the ratifications of Brazil and Paraguay, having been ratified only by Uruguay and Argentina as of 18 June 2015.

${ }^{62}$ See S. Burchi, 'A Comparative Review of Contemporary Water Resources Legislation: Trends, Developments and an Agenda for Reform', 37:6 Water International (2012), 613.

${ }^{63}$ Namibia Water Resources Management Act, 2004 (Act No.24 of 2004); see also S. Burchi, n. 62 above.

${ }^{64}$ Zambia Water Resources Management Act, 2011 (Act No.21 of 2011). The authors would like to thank Stefano Burchi for pointing this out to them during an international water law training programme held in Gaborone, Botswana, in May 2015.

${ }^{65}$ By doctrinal analysis we refer to the 'attempt to determine what the legal norms are and how those norms apply to particular situations'; D. Bodansky, The Art and Craft of International Environmental Law (Harvard University Press, 2009), at 5.
} 
The first two features to highlight refer to the nature of the provisions in the Guarani Aquifer Agreement; the other two characteristics refer to the institutional options for the further operationalization of the Agreement.

The Guarani Aquifer Agreement is very general, but can be seen as very specific in some respects. It is general because it provides a flexible framework for cooperation. Most of the provisions are not particularly detailed, and the Agreement can best be viewed as a starting point, rather than a place in which all the answers can be found to any management question. Firmly rooted in the principle of sovereignty over natural resources, ${ }^{66}$ but balanced by a direct reference to other general applicable rules of international law, ${ }^{67}$ the Agreement contains most of the key substantive and procedural obligations present in modern international water law. The four Guarani Aquifer System countries are required to: use the aquifer in order to ensure 'multiple, reasonable, sustainable, and equitable use of its water resources', ${ }^{68}$ not cause significant harm to their neighbouring States; ${ }^{69}$ provide prior notification should planned activities be likely to cause effects to parts of the aquifer beyond their borders; ${ }^{70}$ exchange information about the aquifer; ${ }^{71}$ and protect the aquifer. ${ }^{72}$

While these provisions are framed in rather general terms that require (as is usually the case) some degree of interpretation and application based on the circumstances of each utilization of the aquifer, there is another provision that is more specific. Article 14 of the Guarani Aquifer Agreement foresees the possibility that the Guarani Aquifer System countries identify 'critical areas' (where pollution or overexploitation of groundwater is more problematic) and adopt special measures for the management of such areas. The provision does not explain what kind of measures are envisaged; this will depend on the nature of the area of the aquifer and the nature of the threats to the aquifer in such an area. An example of what this could look like comes from a very recent development in TBA law and policy, namely the agreement between Jordan and Saudi Arabia on the Disi Aquifer. ${ }^{73}$ In this case, the agreement establishes both a restricted protection and management area in which activities on the aquifer are limited..$^{74}$ Returning to the Guarani Aquifer Agreement, the relevance of Article 14 is that it provides legal grounds for the adoption of specific measures by the future institution that will govern and manage the Guarani Aquifer System. This provision, requiring specific action for special parts of the aquifer, arguably stems from the experience with two transboundary pilot projects

\footnotetext{
${ }^{66}$ Guarani Aquifer Agreement, n. 1 above, preamble and Articles 2-3.

${ }^{67}$ Ibid., Article 2. The debate over sovereignty has sparked a lot of debate in the literature; see S.C. McCaffrey, 'The International Law Commission's flawed Draft Articles on the Law of Transboundary Aquifers: The Way Forward', 36:5 Water International (2011), 566; O. McIntyre, 'International Water Resources Law and the International Law Commission Draft Articles on Transboundary Aquifers: A Missed Opportunity for CrossFertilisation?', 13:3 International Community Law Review (2011), 237; G.E. Eckstein, 'Managing Buried Treasure across Frontiers: The International Law of Transboundary Aquifers', 36:5 Water International (2011), 573.

${ }^{68}$ Guarani Aquifer Agreement, n. 1 above, Article 4.

${ }^{69}$ Ibid., Article 3.

${ }^{70}$ Ibid., Article 9.

${ }^{71}$ Ibid., Articles 8-12.

72 Ibid., Article 4.

${ }^{73}$ Disi Aquifer Agreement, n. 14 above.

${ }^{74}$ Ibid., Article 2.1, requires '[t]he elimination of all activities in the Protected Area (the Prohibited Area)' and Article 2.5 mandates ' $[\mathrm{t}]$ he protection of groundwater in the Management Area between the two States from any pollution. It is not permissible to inject any pollutant, whatever its quality or quantity, into the groundwaters in the Management Area'.
} 
undertaken in the Guarani project that underscored the importance of cooperation in a more localized part of the aquifer, where the pressures are more urgent. ${ }^{75}$

Accordingly, it is necessary to explore the possible institutions that will be tasked to manage the aquifer. Article 15 of the Guarani Aquifer Agreement makes it very clear that a Commission charged with the management of the Guarani Aquifer System will be established under the framework of the Treaty of the River Plate Basin. ${ }^{76}$ The option that has been agreed is to link a transboundary agreement with an already established legal and institutional framework whose main competence is to deal with transboundary surface water. The other option was to leave the two separated, and to create an ad hoc institutional framework devoted solely to the management of the Guarani Aquifer System. Considerations of efficiency argued against an $\mathrm{ad}$ hoc institutional system. Interestingly, the membership of the Treaty of the River Plate Basin does not overlap completely with the countries sharing the Guarani Aquifer System, since Bolivia is also part of the Treaty of the River Plate Basin. Nonetheless, this was no impediment to specifying a role for the Treaty of the River Plate Basin Commission in the management of the aquifer. One interesting development is that, if and when the Agreement enters into force, the Commission under Article 15 of the Guarani Aquifer Agreement may become the institution in charge for the management not just of the Guarani Aquifer System, but also for other TBAs that can be found beneath the Plate Basin, which are currently being studied in a further GEF project. ${ }^{77}$

Finally, the Guarani Aquifer Agreement lacks a clear dispute settlement provision. In the 2005 draft agreement that was being negotiated, such a provision was present, together with a detailed annex elaborating how arbitration should take place. ${ }^{78}$ This provision was deleted, and this is where the speculation can begin. Has this triggered the adoption of the Guarani Aquifer Agreement? It could be argued that the dispute settlement provision proved too controversial and undermined the entire negotiations that took place in 2005. When these resumed in 2010, and this provision and the annex were deleted, the four countries reached agreement rather quickly. ${ }^{79}$ Whatever interpretation is correct, the absence of a dispute settlement provision in the Guarani Aquifer Agreement may prove challenging should countries disagree on the interpretation of any specific provision.

\section{EMERGING TBA GOVERNANCE IN THE SADC REGION}

While the region lacks ad hoc arrangements for transboundary aquifers, there is a wealth of experience in the SADC in the field of transboundary surface water law and policy. At the regional level, the 2000 SADC Revised Protocol very closely follows the guidelines set out in the United Nations Watercourses Convention. ${ }^{80}$ The Protocol encourages countries to negotiate separate agreements over transboundary watercourses in the region and to create institutions to manage such treaties. ${ }^{81}$ Currently, there are up to 15 shared river basins in the SADC but only

\footnotetext{
${ }^{75}$ See SAP, n. 22 above.

${ }^{76}$ Treaty of the River Plate Basin (Brasilia, 23 April 1969; in force 14 August 1970) (Agreement between Brazil, Argentina, Bolivia Paraguay and Uruguay); see also Z.P. Sugg et al., n. 54 above.

${ }^{77}$ The GEF project is titled 'Sustainable Management of the Water Resources of the La Plata Basin with Respect to the Effects of Climate Variability and Change' (project ID 2095); see <http://iwlearn.net/iw-projects/2095>.

${ }^{78}$ On file with authors.

${ }^{79}$ See F. Sindico, n. 45 above.

${ }^{80}$ SADC Revised Protocol, n. 2 above; see UN Convention on the Law of the Non-navigational Uses of International Watercourses (New York, 21 May 1997; in force 17 August 2014) ('UN Watercourses Convention').

${ }^{81}$ Ibid., Article 5.
} 
six of these have a dedicated commission. ${ }^{82}$ This existing institutional framework is therefore considered in the absence of an aquifer specific agreement, with a view to identifying emerging trends towards TBA governance in the region.

If the institutional option chosen for the Guarani Aquifer Agreement - linking the management of a TBA to that of a transboundary river basin - were to be followed in the SADC region, this option could fit comfortably with the wider transboundary water governance landscape in the SADC. In fact, policy makers in the SADC have called for this specifically, ${ }^{83}$ mentioning that the emerging attention for TBAs should be linked to already existing transboundary river commissions. If that were the case, the two TBAs that appear to have gathered some momentum in terms of international project activities, the Stampriet and the Ramotswa, could fall under the mandate of ORASECOM and LIMCOM treaties respectively. Interestingly, as is the case for the Treaty of the River Plate Basin, there are countries that would not have a direct interest in the management of the TBA. Similarly to Bolivia in the case of the Guarani Aquifer System, this would include Lesotho in the case of the Stampriet, and Mozambique and Zimbabwe in the case of the Ramotswa, since they would not share the TBA in question. However, this would not be an obstacle since both the ORASECOM and LIMOCOM treaties refer to the possibility for specific parties to enter into ad hoc agreements. ${ }^{84}$

If the countries sharing the Stampriet or the Ramotswa were to consider the ORASECOM and LIMCOM treaties and their commissions to manage the specific TBA, the question arises as to whether these agreements already cover groundwater and, potentially, transboundary aquifers. This is the case for the LIMCOM treaty, which defines the Limpopo watercourse as a system of surface and groundwaters of the Limpopo ${ }^{85}$ Conversely, the ORASECOM treaty does not define 'river system', and merely includes a brief reference to the 'hydrogeological' condition of the river system, ${ }^{86}$ which could imply that groundwater connected to surface water is included in the system itself. On the other hand, especially in its provisions about the obligation of the parties, the ORASECOM treaty goes into great lengths to discuss obligations in relation to specific parts of the river system, such as the estuary. ${ }^{87}$ While the analysis so far does not seem to lean towards the inclusion of groundwater in the work of ORASECOM, a closer look at the preamble suggests that it does so indirectly through the reference to the United Nations Watercourses Convention. ${ }^{88}$ The preamble also refers to the fact that ORASECOM has been inspired by the SADC Revised Protocol. The latter does include a definition of 'watercourse' that resembles the one provided for in the United Nations Watercourses Convention, which includes groundwater inasmuch as it is connected to surface water. ${ }^{89}$ More convincingly than the treaty itself, the structure that has been devised by the parties for its functioning reveals that

\footnotetext{
${ }^{82}$ These are the Commission Internationale du Bassin Congo-Oubangui-Sangha, the Permanent Joint Technical Committee Kunene, the Limpopo Watercourse Commission, the Permanent Okavango River Basin Water Commission, the Orange-Senqu River Commission and The Zambezi Watercourse Commission. See SADC, 'Water Information Services and Portals', found at: <http://www.sadc.int/themes/natural-resources/water/>.

${ }^{83}$ P. Beetlestone and E. Braune, 'Groundwater in the SADC Integrated Water Resources Management Initiative: Workshop Report, 18-19 November 2008, Botswana' (SADC, 2008).

${ }^{84}$ ORASECOM Treaty, n. 3 above, Article 1.4; LIMCOM Treaty, n. 4 above, Article 2.5.

${ }^{85}$ LIMCOM Treaty, n. 4 above, Article 1.2.

${ }^{86}$ Ibid., Article 7.4.

${ }^{87}$ Ibid., Article 7.14.

${ }^{88}$ UN Watercourses Convention, n. 80 above, Article 2.a: "“Watercourse” means a system of surface waters and groundwaters constituting by virtue of their physical relationship a unitary whole and normally flowing into a common terminus'.

${ }^{89}$ SADC Revised Protocol, n. 2 above, Article 1.1: 'Watercourse system means the inter-related hydrologic components of a drainage basin such as streams, rivers, lakes, canals and underground water which constitute a unitary whole by virtue of their physical relationship'.
} 
ORASECOM is mandated to deal with groundwater-related matters. In fact, in addition to a decision-making body (Council) and an administrative body (Secretariat), there are four Technical Task Teams, one of which includes a 'Hydrogeology Committee' .90

While other transboundary river agreements in the SADC may provide for a clearer mandate for groundwater and, potentially, transboundary aquifers, ${ }^{91}$ the ORASECOM and LIMCOM can be used as institutions for the future management of the two specific TBAs. However, the treaties and most of the institutional structures created by them are geared towards transboundary surface water. Where rules do consider groundwater, the agreements certainly do not provide for holistic management of the aquifer system, as opposed to just the water contained therein. If the ORASECOM and LIMCOM treaties and their respective commissions are to play any role in the management of TBAs, tailored rules should be carefully considered. Whether the characteristic differences between these aquifers and the wider river basins in which they are situated warrant completely separate and aquifer-specific legal agreements (as in the case of the Guarani Aquifer Agreement), is yet to be seen. What is more important at this point is that SADC countries are warming to the idea that regional water policy is not just about surface water and transboundary river agreements, but requires also attention to TBAs and their management.

Unlike the Guarani Aquifer Agreement, the institutional arrangements in the SADC offer detailed dispute mechanisms, although their practical applicability is tenuous. The overarching SADC Revised Protocol states that the parties 'shall strive to resolve all disputes regarding the implementation, interpretation or application of the provisions of this Protocol amicably', while disputes 'which are not settled amicably shall be referred to the [SADC] Tribunal' ${ }^{92}$ In addition, both the ORASECOM and LIMCOM treaties provide detailed dispute resolution provisions with time limits, which also defer to the authority of the SADC Tribunal. ${ }^{93}$ However, the SADC Tribunal has been suspended since 2012, once again demonstrating that such mechanisms are severely limited by the principle of State consent. ${ }^{94}$ The disbanding of the SADC Tribunal also illuminates the fact that the establishment of such mechanisms is by no means future-proof. While the implementation challenge for the Guarani Aquifer Agreement can be characterized by the absence of dispute settlement provisions in the Agreement itself, the obstacles for the SADC region lie in the failure of regional mechanisms, in spite of the existence of thorough legal provisions. It may therefore be useful to consider the cooperative environment at local level 'hot spots,' in cases where State relations prove problematic.

Similar to the Guarani Aquifer, the need for groundwater management to be decentralized to various local hotspots has been identified in the SADC region. ${ }^{95}$ Despite this, the existing agreements remain relatively State-centric in their approach to cooperation. Although the LIMCOM and ORASECOM treaties acknowledge local issues through provisions requiring

\footnotetext{
${ }^{90} \mathrm{See}<\mathrm{http}: / /$ www.orasecom.org/about/structure.aspx $>$.

${ }^{91}$ Agreement on the Establishment of the Zambesi Watercourse Commission (Kasane, Botswana, 13 July 2004; in force 26 June 2011), Article 1: 'Zambesi Watercourse means the system of surface and ground waters of the Zambesi constituting by virtue of their physical relationship a unitary whole flowing normally into a common terminus, the Indian Ocean'.

92 SADC Revised Protocol, n. 2 above, Article 7.

93 ORASECOM Treaty, n. 3 above, Article 8; LIMCOM Treaty, n. 4 above, Article 9.

${ }^{94}$ L. Nathan, 'The Disbanding of the SADC Tribunal: A Cautionary Tale', 35:4 Human Rights Quarterly (2013), 870 .

${ }^{95}$ W. Scheumann and E. Herrfahrdt, 'Conceptualizing Cooperation on Africa's Transboundary Groundwater Resources’ (German Development Institute, 2008).
} 
public participation, ${ }^{96}$ these provisions do not detail how this should be achieved, and there remains a lack of formal transboundary arrangements enabling localized cooperation for TBAs at the border. However, opportunities for local cooperation exist in areas with transnational parks. For example, the Stampriet Aquifer underlies the Kgalagadi Transfrontier Park, for which a joint management committee exists between South Africa and Botswana to manage the area as a single ecological unit. ${ }^{97}$ Forming a legal link between the watercourse treaties and existing institutions for cooperation at the transnational yet local level may provide opportunities for joint management of TBA hotspots which, like the Guarani Aquifer, have more urgent pressures to address. Where institutions do not yet exist, 'critical areas' and the development of local institutions may be a useful consideration for TBA governance in the SADC region.

\section{COMPARING APPLES AND ORANGES?}

We now reflect upon the utility of a comparative assessment of this nature. In light of the above analysis, we consider two questions. First, we investigate the long-standing debate of comparing apples and oranges, by inquiring into whether it is even possible to compare the legal regimes of transboundary aquifers, given their unique characteristics affecting regulatory priorities. Second, we contemplate the little-tested approach of comparing an existing international legal instrument with something that is essentially non-existent. We conclude that such an analysis can be conducted and replicated in other cases, as long as the purpose of the exercise is appreciated as a process of knowledge acquisition.

\section{TOO MANY VARIABLES: A FRUITLESS ANALYSIS?}

A long-standing debate in comparative legal scholarship poses the question of whether you can compare legal systems that are radically different. ${ }^{98}$ Comparative lawyers have traditionally avoided such comparisons, including that of non-State law, on account of their incomparability. ${ }^{99}$ Not only does the above analysis develop the scholarly trend of comparing regional legal systems, ${ }^{100}$ it compares legal systems that aim to regulate a subject matter (that is, transboundary aquifers) that is unique in each case, through both space and time: not only is no aquifer the same, their geology and hydrological processes change over time. This unique subject is then placed in an equally diverse political and cultural context, risking a potentially 'fruitless' comparison. ${ }^{101}$ On what basis, then, can comparisons be drawn between two case studies with so many variables?

In answering this question it is useful to consider the purpose of comparative law at the international level, which is often said to be the unification of law. ${ }^{102}$ As the world becomes increasingly interconnected, concepts such 'transnational governance' emphasize a need to be informed by the underpinning legal systems of nations. Similarly, in order to reach 'the best decision' in international negotiations, there is value in assessing existing models, which can

\footnotetext{
${ }^{96}$ ORASECOM Treaty, n. 3 above, Article 5.2.4; LIMCOM Treaty, n. 4 above, Article 7.2(c).

${ }^{97}$ G. Thondhlana, S. Shackleton and J. Blignaut, 'Local Institutions, Actors, and Natural Resource Governance in Kgalagadi Transfrontier Park and Surrounds, South Africa', 47 Land Use Policy (2015), 121.

${ }^{98}$ See, e.g., C. Valcke, 'Comparative Law as Comparative Jurisprudence - The Comparability of Legal Systems', 52:3 American Journal of Comparative Law (2004), 713.

${ }^{99}$ M. Siems, Comparative Law (Cambridge University Press, 2014), at 25.

${ }^{100}$ M. Siems, 'Human Rights Treaties and Comparative Law', 171:1 Journal of Institutional and Theoretical Economics (2015), 118.

${ }^{101}$ See M. Siems, n. 99 above, at 27.

${ }^{102}$ Ibid., at 4.
} 
form the basis of new international agreements. ${ }^{103}$ Comparative law is also said to be relevant for sources of public international law in its connection with identifying customary international law, ${ }^{104}$ or creating a basis for interpretation in the International Court of Justice. In these cases, not only is the comparison of radically different legal systems beneficial, it is imperative to avoid the development of notions of 'universal' law and values that are primarily rooted in Western/European legal tradition, and are thus not applicable to other legal cultures. ${ }^{105}$

The applicability of international legal principles in regional and national legal systems is considered in the above analysis. For example, the significance of the sovereignty principle in the Guarani Aquifer Agreement directly relates to the surrounding geopolitical context, where intrusions of national sovereignty are resisted by States in response to civil society concerns. There are weaker references to sovereignty in existing SADC regional policy and surface water agreements, which may suggest that national sovereignty concerns in relation to water resources are not necessarily replicated in the SADC. This is partly demonstrated through the less resistant attitudes towards international donors, as highlighted above. Thus, comparing radically different systems can test the flexibility of international legal frameworks when applied to different regional contexts. With the General Assembly due to decide the fate of the UN ILC's Draft Articles in 2016, ${ }^{106}$ such an observation about the controversial sovereignty provision could have significant implications for the development of these rules in the future. This article can accordingly form the basis for future research examining this principle in more depth, with reference to other regional approaches.

The merits of the analysis carried out here do not necessarily reside in its ability to produce policy impacts, as the radical differences between aquifers, regional geopolitics and regional legal systems should be clear. However, identifying the unique and specific characteristics of aquifer systems and their associated legal rules can be of help to the international and/or transboundary lawmaking process. This is important, since framework agreements must be flexible in their application to different and varying contexts. This article's comparative analysis has identified the existing legal infrastructure that can enable implementation in both regions, the socio-economic activities surrounding aquifer use, the populations dependent on the aquifer, as well as the geopolitical context that can affect political will. The importance of investigating certain characteristics and different uses may not be appreciated when looking solely at one aquifer system and its surrounding legal structures. This article therefore demonstrates that the benefit of comparing apples and oranges is the process of the comparison itself, as opposed to any direct conclusions that can be drawn for one particular legal system. As Zweigert and Kötz suggest, like any other science, the aim of comparative law is generating knowledge. ${ }^{107}$

\section{A MEANS TO AN END?}

\footnotetext{
${ }^{103}$ G. Mousourakis, Perspectives on Comparative Law and Jurisprudence (Pearson Education, 2006), at 11-12.

104 G.A. Bermann et al., 'Comparative Law: Problems and Prospects', 26:4 American University International Law Review (2011), 935, at 938.

105 See M. Siems, n. 99 above, at 35-37.

${ }^{106}$ Report of the Sixth Committee, The Law of Transboundary Aquifers (UN Doc. A/68/470, 19 November 2013), at paragraph 3.

${ }^{107}$ K. Zweigert and H. Kötz, An Introduction to Comparative Law, $3^{\text {rd }}$ edn (Oxford University Press, 1998), at 1617.
} 
The second feature of this analysis is the little-tested approach of comparing an existing aquifer-specific international legal instrument with something that is apparently non-existent. It follows that this analysis could help inform the development of law governing transboundary aquifers in the SADC region, through drawing lessons from the agreement reached in the Guarani Aquifer System. This method presumes that an effective policy approach is to 'transplant' one legal system to another. ${ }^{108}$ However, the previous section demonstrates the uselessness of a legal transplant in this context. The differing climatic conditions and populations 'served' by the aquifers alone warrant a different type of regulatory attention.

Accordingly, the utility of the above comparative analysis lies in distinguishing the two systems by looking at the underpinning legal instruments. While no bilateral or multilateral agreement specific to any aquifer currently exists in the SADC, there are several existing transboundary surface water agreements that could have a mandate to also cover TBAs, as we have seen with the ORASECOM and LIMCOM treaties. Thus, it may be erroneous to assume that no legal regime exists at all for TBAs in regions where aquifer-specific agreements are absent. However, we have also seen that the existing mandate can be very weak, and that in any case the existing international legal instruments in the SADC region that could cater for TBAs are geared almost entirely for the management of transboundary surface water. Nevertheless, existing institutional structures can serve as a foundation from which to build regulatory cooperation on shared aquifer systems. The process of comparing an existing treaty with a non-existent treaty undertaken in this article allows a departure from the increasingly rejected State-centric approach to comparative, and international law, by appreciating the institutional processes on different levels. This can produce a richer analysis and also help put the comparison in the correct geopolitical and cultural context. Again, it is the process of the comparison that is enlightening, as opposed to the need for direct policy recommendations.

\section{CONCLUSION}

This article has sought to address the question of whether apples and oranges can be compared in international environmental law. By apples and oranges we mean two international legal instruments placed in contexts that are so different that they usually would not be compared. In this case, the comparative exercise is complicated further since it takes place between an existing (albeit not yet in force) international legal instrument, the Guarani Aquifer Agreement, and a missing one for the management of transboundary aquifers in the SADC.

We have argued that a comparative exercise of this nature is indeed possible, as long as its goal is not to highlight a management practice that could be considered as a model for another setting. The comparative exercise can be valuable if it is constructed as knowledge sharing between one region that has gained experience with a certain management practice and another region that has yet to gain such experience. In the comparative exercise undertaken in this article, we have identified several trends arising from the management of the Guarani Aquifer System that could be worth sharing with SADC countries currently embarking on the initial stages of the management of a TBA. Specifically, the lessons worth sharing include adapting the institutional setting based on pre-existing transboundary surface water treaties and the combination of both general and very specific provisions, and including the identification of 'critical areas' for localized cooperation at the border. In particular, the practice that an ad hoc treaty (the Guarani Aquifer Agreement) has identified an already established transboundary surface water treaty system (the River Plate Basin treaty) as the management platform for the

${ }^{108}$ Ibid., at 15 . 
TBA is of particular interest. A similar pattern could emerge for two TBAs in the SADC region that are currently being studied in the framework of ongoing international projects. The responsibility for management of the Stampriet and Ramotswa aquifers could be assigned to the ORASECOM and LIMCOM, respectively,. In addition, a multi-level approach may address the challenges associated with the absence of an ad hoc adversarial dispute settlement system, although this issue requires further research.

In conclusion, a comparative analysis of international environmental law should not shy away from difficult and unorthodox comparisons, although it should not be expected to produce law and policy recommendations. Comparing the Guarani Aquifer Agreement to the range of institutions potentially applicable to TBAs in the SADC region can be a useful exercise only if those undertaking the comparison are aware of its limits. The comparison serves primarily to generate and share knowledge. The experience in the Guarani Aquifer System region can be shared with those stakeholders and policy makers who are interested in promoting further TBA management in the SADC. However, lessons learnt from the Guarani Aquifer System management experience need to be carefully understood against the specific geopolitical and socio-economic context of Latin America. Comparative analysis of legal instruments for transboundary aquifers across regions thus serves as an explorative exercise to increase the knowledge base needed to advance this highly underdeveloped area. This is imperative for the upcoming discussions regarding the future for transboundary aquifer law, which are gaining momentum at the international level.

Francesco Sindico is a Reader in International Environmental Law at the University of Strathclyde Law School, where he also acts as Director of the Strathclyde Centre for Environmental Law and Governance and as Programme Director of the LLM in Climate Change Law and Policy. His work in the field of international water law focuses mainly on the management of transboundary aquifers, but he also works on water and human rights, water and international trade, and international water governance. Dr Sindico collaborates with UNESCO-IHP (International Hydrological Programme) and with the ISARM (International Shared Aquifers Resource Management) Programme hosted by UNESCOIHP. He has also served as a member of the Legal Experts Group to the Groundwater Governance project and as a member of the Legal Experts Group advising the African Ministerial Council on Water in the development of the statutes of its Groundwater Commission. Dr Sindico is also an Expert in International Environment, Energy \& Natural Resources Law at the London Centre for International Law Practice.

Stephanie Hawkins is a $\mathrm{PhD}$ researcher in transboundary aquifer law and policy at the University of Strathclyde Centre for Environmental Law and Governance. 